\title{
PENGARUH PERAN PERAWAT SEBAGAI CARE GIVER TERHADAP LENGTH OF STAY (LOS) DI IGD RSUD DR.T.C.HILLERRS MAUMERE DENGAN PELAKSANAAN TRIAGE SEBAGAI VARIABEL MODERASI \\ Yuliani Pitang ${ }^{1}$, Edi Widjajanto ${ }^{2}$, Dewi Kartikawati Ningsih ${ }^{3}$ \\ ${ }^{1}$ Universitas Nusa Nipa Nusa Tenggara Timur \\ ${ }^{2,3}$ Fakultas Kedokteran Universitas Brawijaya Malang
}

\begin{abstract}
ABSTRAK
Setiap tahun, lebih dari 2 juta orang/tahun datang mengunjungi IGD dan tidak jarang terjadi penumpukan pasien atau overcrowded yang menjadi masalah serius yang terjadi di IGD, dimana hal ini menyebabkan waktu tunggu yang lama dan ketidakpuasan pasien terhadap pelayanan di IGD. LOS merupakan indikator yang efektif untuk menilai kinerja dari IGD dan kualitas dari triage, hal ini menuntut perawat IGD untuk selalu menjalankan perannya di berbagai situasi dan kondisi yang meliputi tindakan penyelamatan pasien secara profesional. Metode yang digunakan kuantitatif observasional analitik dengan pendekatan studi penampang analitik (analytic cross sectional study), jumlah sampel yang digunakan 20 responden untuk subjek perawat dan 100 responden untuk subjek pasien dengan quota sampling. Hasil uji chi square ( $p$ value $<0,05$ ) menunjukan tidak ada pengaruh peran perawat sebagal care giver terhadap lenght of stay pasien di IGD dengan nilai signifikansi 0,649 dan penentuan pengaruh triage terhadap LOS pasien dilakukan dengan uji fisher menunjukan bahwa tidak memberikan pengaruh terhadap LOS pasien dengan nilai signifikansi 0,410 ( $p$ value $<0,05$ ). Kesimpulan adalah tidak ada pengaruh peran perawat sebagai care giver dengan LOS pasien dengan pelaksanaan triage sebagai variabel moderasi. Adapun faktor-faktor yang mempengaruhi LOS diantaranya waktu kedatangan, waktu konsultasi, waktu pemeriksaan lab, waktu pemeriksaan radiologi dan waktu disposisi fisik, dan ketersediaan tempat tidur di unit lain. Berdasarkan hasil penelitian tersebut diatas maka dianggap perlu untuk menyempurnakan hasil penelitian ini dengan memperbaiki setiap kekurangan yang ada, diantaranya menambah jumlah sampel, menambah waktu penelitian, memperbaiki metode observasi dan melakukan penelitian lebih lanjut terhadap faktor-faktor yang berpengaruh terhadap LOS pasien.
\end{abstract}

Kata Kunci : Peran perawat Care Giver, Triage, Length Of stay pasien

\begin{abstract}
Every year, more than 2 million of people/year comes to ED and it is not occasionally occur overcrowded that is being serious problem in ED, where it cause longer length of stay and dissatisfaction of patients toward service in ED. LOS is effective indicator to appraise performance in ED and quality of triage. It demands EDnurse to be always conducting their roles in such situations and conditions that include patients' treatment in professional. Method used in this study is analytic observational quantitative with analytic cross sectional study, the number of sample used is 20 respondents for nurse subject and 100 respondents for patients subject with quota sampling. Result from chi square test showed that alpha is $0,649(>0,05)$ indicated that there are no influences of nurse role as care giver with length of stay patients in ED and the determination of triage is not influence toward LOS patients that indicated from fisher test which had alpha 0,410 $(>0,05)$. From these study can be concluded that there is no influence on nurse as care giver with patients' LOS by implementing triage as moderation variable. The influencing factors of LOS are visiting time, consultation time, lab examination time, radiology examination time and physical disposition time, and bed availability on other unit. Based on the result of study above, it is regarded that there is needed completeness on the result of this study by improving each weakness, namely the addition on the number of sample, the addition of study time, improving observation method and conducting further study toward the influencing factors toward patients Length Of stay.
\end{abstract}

Keywords: The Role of Care Giver Nurse, Triage, Patients Length of Stay

Jurnal Ilmu Keperawatan, Vol: 4 No.2; Korespondensi : Yuliani Pitang. Universitas Nusa Nipa NTT. Alamat: Jln. Anyelir No. 31 Perumnas Kec.Alok, Kab. Sikka Maumere Flores NTT 86112. Email: julianipitank@yahoo.co.id No Hp. 082340184363 


\section{PENDAHULUAN}

Kondisi gawat darurat merupakan keadaan klinis dimana pasien membutuhkan tindakan medis segera guna penyelamatan nyawa serta pencegahan kecacatan lebih lanjut (UndangUndang Republik Indonesia No.44, 2009). Penanganan gawat darurat ada filosofinya yaitu Time Saving it's Live Saving. Artinya seluruh tindakan yang dilakukan pada saat kondisi gawat darurat haruslah benar-benar efektif dan efisien. Hal ini mengingatkan pada kondisi tersebut pasien dapat kehilangan nyawa hanya dalam hitungan menit saja. Berhenti nafas selama 2-3 menit pada manusia dapat menyebabkan kematian yang fatal (Sutawijaya, 2009).

Dalam upaya untuk meningkatkan kualitas IGD, peran perawat sangatlah penting. Perawat IGD dituntut untuk selalu menjalankan perannya di berbagai situasi dan kondisi yang meliputi tindakan penyelamatan pasien secara profesional khususnya penanganan pada pasien gawat darurat. Sebagai pelaku atau pemberi asuhan keperawatan perawat dapat memberikan pelayanan keperawatan secara langsung atau tidak langsung kepada pasien dengan menggunakan pendekatan proses keperawatan yang meliputi : pengkajian dalam upaya mengumpulkan data, menegakkan diagnosis keperawatan berdasarkan hasil analisis data, merencanakan intervensi keperawatan sebagai upaya mengatasi masalah yang muncul dan membuat langkah atau cara pemecahan masalah, melaksanakan tindakan keperawatan sesuai dengan rencana yang ada dan melakukan evaluasi berdasarkan respon pasien terhadap tindakan keperawatan yang telah dilakukannya (Barbara, 2010).

Triage merupakan salah satu keterampilan keperawatan yang harus dimiliki oleh perawat unit gawat darurat dan hal ini membedakan antara perawat unit gawat darurat dengan perawat unit khusus lainnya. Karena harus dilakukan dengan cepat dan akurat maka diperlukan perawat yang berpengalaman dan kompeten dalam melakukan. Perawat sebaiknya mempunyai pengalaman dan pengetahuan yang memadai karena harus terampil dalam pengkajian serta harus mampu mengatasi situasi yang komplek dan penuh tekanan sehingga memerlukan kematangan profesional untuk mentoleransi stres yang terjadi dalam mengambil keputusan terkait dengan kondisi akut pasien dan menghadapi keluarga pasien (Elliott et al, 2007).

Setiap tahun, lebih dari 2 juta orang/tahun datang mengunjungi IGD. Tidak jarang terjadi penumpukan pasien atau overcrowded yang menjadi masalah serius yang terjadi di IGD, dimana hal ini menyebabkan waktu tunggu yang lama dan ketidakpuasan pasien terhadap 
pelayanan di IGD. Yoon et al (2003) menjelaskan bahwa terlambatnya proses penanganan serta LOS pasien di IGD merupakan kunci untuk mengukur terjadinya overcrwoded di IGD. Waktu dianggap sebagai alat yang penting untuk mengukur kualitas dari pelayanan di IGD. Masalah waktu tunggu yang panjang dan lama menunjukan IGD yang buruk dengan sumber daya yang kurang berhasil dan tidak terkoordinasi dengan baik (Bukhari et al, 2014).

Pada tahun 2004, The National Health Service (NHS) di Inggris menetapkan target bahwa tidak ada yang harus menunggu lebih dari 4 jam di IGD. Penelitian yang dilakukan oleh Bukhari et al, (2014) mengevaluasi waktu tunggu pada pasien di IGD dimana mengadaptasi target waktu tunggu oleh NHS yaitu 4 jam. Penelitian ini juga mengevaluasi kembali LOS pasien di IGD serta faktor yang mempengaruhinya. LOS dikaitkan dengan waktu kedatangan, triage, waktu konsultasi, waktu pemeriksaan lab, waktu pemeriksaan radiologi dan waktu disposisi fisik.

Pada instalasi gawat darurat total Length of Stay (LOS) dan Waiting time digunakan untuk melihat tingkat kepadatan dan kinerja klinis. Pengukuran LOS setiap pasien diukur dari awal kedatangan pasien sampai dengan perpindahan pasien ke unit lain yang digunakan sebagai indikator kunci penilaian efesiensi peningkatan kinerja operasional dan klinis (Niels et al, 2012). LOS merupakan indikator yang efektif untuk menilai kinerja dari IGD dan kualitas dari triage. LOS yang memanjangberhubungan erat dengan kualitas triage dan kinerja pelayanan keperawatan di IGD (Yoon, 2003; Bukhari et all, 2014; Lewil et al, 2014; Parker, 2014).

Pada tahun 2010, Pemerintah Australia memperkenalkan National Emergency Access Target (NEAT), yang mensyaratkan bahwa sebagian pasien yang datang ke ruang gawat harus dipindahkan keruang perawatan lainnya dalam waktu 4 jam. Pada tahun 2015, 90\% dari semua pasien yang datang ke ruang gawat darurat telah dipindahkan keruang perawatan dalam 4 jam untuk memenuhi program tersebut (Australian Government Department of Health and Ageing, 2011). Inisiatif ini mencontoh skema yang digunakan di Inggris. Pada tahun 2000, Inggris meluncurkan Rencana Layanan Kesehatan Nasional dengan maksud meningkatkan pengiriman dan akses ke perawatan kesehatan dan menyatakan bahwa pada tahun 2004 tidak ada yang harus menunggu lebih dari 4 jam di ruang gawat darurat (Mortimore \& Cooper, 2007).

Dalam upaya untuk memperpendek lenght of stay, beberapa ruaang gawat darurat telah meningkatkan lingkup praktik keperawatan, yang memungkinkan perawat untuk segera Jurnal Ilmu Keperawatan - Volume 4, No. 2 November 2016 
merespon pasien dan melakukan tindakan termasuk tes darah, pemberian analgetik dan radiografi. Perawat telah terbukti secara signifikan mengurangi waktu untuk penilaian nyeri dan telah mengurangi lenght of stay pasien. Dalam satu studi rata-rata waktu untuk penilaian nyeri berkurang dari 47 menit menjadi 1 menit, sedangkan waktu untuk administrasi analgesia menurun dari waktu rata-rata 98 menit menjadi 28 menit. Pemeriksaan penunjang yang meliputi tes darah, urine, EKG dan radiografi, telah menunjukkan length of stay pasien semakin lama. Pasien yang membutuhkan tes darah ditemukan untuk tinggal 72 menit lebih lama dari pasien yang tidak membutuhkan tes darah (Kocher, Meurer, Desmond, \& Nallamothu, 2012).

Studi pendahuluan yang dilakukan pada bulan Januari dijelaskan bahwa IGD RSUD dr.T.C.Hillers Maumere telah menerapkan sistem triage dalam penentuan tingkat kegawatdaruratan pasien. Pelaksanaan triage pada rumah sakit dr.T.C.Hillers Maumere sepenuhnya dilaksanakan oleh perawat yang berwenang penuh atas operasional kegiatan di ruang triagesampai dengan penentuan prioritas kegawatdaruratan pasien.

Data selama tahun 2015 menunjukkan jumlah pasien yang berkunjung di IGD berdasarkan tingkat kegawatdaruratan adalah gawat medik sebanyak 603 orang, gawat obgyn sebanyak 603 orang, gawat anak sebanyak 361 orang, gawat bedah sebanyak 170 orang. Rumah Sakit Umum Daerah dr.T.C.Hillers Maumere merupakan Rumah Sakit Daerah Tipe C dan Rumah Sakit Pendidikan. Melalui hasil wawancara dengan kepala ruangan, dijelaskan bahwa waiting time pada IGD dr.T.C.Hillers adalah \pm 30 menit sedangkan LOS adalah $\geq 6$ jam. Namun pada kenyataannya, berdasarkan hasil wawancara terhadap lima pasien hampir semua menjelaskan bahwa pelayanan yang diberikan oleh perawat sangat lama, pasien harus menunggu beberapa saat. Setelah mendapatkan perawatan, pasien juga harus menunggu lebih dari $\geq 10$ jam untuk kemudian dipindahkan ke ruang perawatan. Hasil observasi sementara yang dilakukan peneliti ditemukan bahwa pelayanan terhadap pasien yang true emergency (benarbenar gawat) dirasakan belum maksimal.

Penelitian ini dilakukan dengan tujuan untuk melihat pengaruh peran perawat sebagai caregiver terhadap LOS pasien di IGD RSUD dr.T.C.Hillers Maumere dengan pelaksanaan Triage sebagai Variabel Moderasi.

\section{METODE}

Desain yang digunakan dalam penelitian ini adalah kuantitatif observasional analitik menggunakan pendekatan studi penampang analitik (analityc cross sectional study). Sampel dalam penelitian ini adalah 
20 responden untuk subjek perawat dan 100 responden untuk subjek pasien. Sampel diambil dengan teknik quota sampling.

Surat Keterangan kelaikan etik dikeluarkan oleh Komisi Etik Universitas Nusa Cendana Kupang. Penelitian dilakukan di IGD RSUD dr.T.C.Hillers Maumere pada bulan Juni 2016 dengan melakukan observasi.

\section{HASIL}

Data disajikan dalam bentuk tabel dan narasi yang meliputi gambaran umum responden, hasil analisa univariat dan analisa bivariat.

\section{Gambaran Umum Responden}

Tabel 1 Karakteristik perawat

\begin{tabular}{lllll}
\hline Variabel & Kategori & \multicolumn{2}{c}{ Jenis kelamin } & Total \\
\cline { 3 - 4 } & & $\begin{array}{l}\text { Laki } \\
\text {-laki }\end{array}$ & peremp & \\
& & 2 & 7 & 9 \\
\hline Usia & $>35$ & 0 & 11 & 11 \\
& $\leq 35$ & 2 & 18 & 20 \\
Total & & 0 & 1 & 1 \\
\hline Pendidik & S1 Kep & 2 & 17 & 19 \\
an & D3 Kep & 2 & 18 & 20 \\
Total & & 2 & 11 & 12 \\
Masa & $>$ 5tahun & 1 & 7 & 8 \\
Kerja & 3- & 1 & 7 & 20 \\
Total & 5tahun & 2 & 18 & 18 \\
\hline Pelatihan & PPGD & 1 & 17 & 2 \\
& PPGD- & 1 & 1 & \\
Total & BTLS & & & 20 \\
& & 2 & 18 & \\
\hline
\end{tabular}

(sumber : Output Pengolahan Data SPSS 21)

Berdasarkan tabel di atas, presentase usia perawat pada ruang IGD adalah $45 \%$ berusia $>35$ tahun dan 55\% berusia $\leq 35$ tahun. Pendidikan perawat di IGD dikategorikan dalam jenjang S1 dan D3 keperawatan dengan persentase $5 \%$ menempuh jenjang S1 keperawatan, dan 95\% menempuh jenjang D3 keperawatan. Dalam kategori masa kerja perawat di ruang IGD dikategorikan pada $>5$ tahun dengan persentase jumlah perawat sebesar $60 \%$ dan 3 - 5 tahun sebesar $40 \%$. Seluruh perawat di IGD RSUD dr.T.C.Hillers Maumere sudah mengikuti pelatihan PPGD dengan persentase $90 \%$ dan yang mengikuti PPGD dan BCLS sebesar $10 \%$.

Tabel 2. Karakteristik Pasien

\begin{tabular}{|c|c|c|c|c|}
\hline \multirow[t]{2}{*}{ Variabel } & \multirow[t]{2}{*}{ kategori } & \multicolumn{2}{|c|}{ Jenis kelamin(\%) } & \multirow{2}{*}{$\begin{array}{c}\text { Total } \\
\text { (\%) }\end{array}$} \\
\hline & & $\begin{array}{c}\text { Laki- } \\
\text { laki }\end{array}$ & perempuan & \\
\hline Usia & Bayi & 11 & 10 & 21 \\
\hline \multirow[t]{3}{*}{ Pasien } & Anak & 5 & 6 & 11 \\
\hline & Dewasa & 38 & 30 & 68 \\
\hline & & 54 & 46 & 100 \\
\hline \multicolumn{5}{|l|}{ Total } \\
\hline \multirow[t]{2}{*}{ Kasus } & Trauma & 14 & 8 & 22 \\
\hline & Non & 40 & 38 & 78 \\
\hline Total & trauma & 54 & 46 & 100 \\
\hline
\end{tabular}

Tabel 2 menunjukan usia pasien dikategorikan menjadi 3 kategori yaitu bayi, anak dan dewasa dengan persentase bayi sebesar $21 \%$, anak sebesar $11 \%$ dan dewasa sebesar 68\%. Persentase pasien anak mendapat penanganan di IGD sangat kecil hanya $10 \%$ dari 100 pasien sampel penelitian. Pengkategorian kasus pasien dikategorikan menjadi kasus traum dan non trauma dengan persentase kasus trauma sebesar $22 \%$ dan non trauma sebesar $78 \%$.

\section{Analisis Univariat}

Analisis univariat meliputi analisis masing masing variabel yaitu peran perawat sebagai 
care giver, pelaksanaan triage, dan LOS pasien.

Tabel 3 Data Peran perawat sebagai care giver

\begin{tabular}{ccc}
\hline variabel & Kategori & $\%$ \\
\hline Care giver & Baik & 44 \\
& Kurang Baik & 56 \\
\hline Total & & 100 \\
\hline
\end{tabular}

(Sumber: Output Pengolahan Data SPSS 21)

Tabel 3 menunjukan bahwa peran perawat sebagai care giver dengan kategori baik sebesar $44 \%$ dan yang kurang baik sebesar $56 \%$.

\section{Tabel 4 Data Pelaksanaan Triage}

\begin{tabular}{ccc}
\hline Variabel & Kategori & $\%$ \\
\hline Triage & Tepat & 99 \\
& Tidak tepat & 1 \\
\hline Total & & 100 \\
\hline
\end{tabular}

(sumber:Output Pengolahan Data SPSS 21)

Tabel 4 menunjukan bahwa pelaksanaan triage untuk kategori tepat sebesar 99\% dan kategori tidak tepat $1 \%$.

\section{Tabel 5. Data LOS Pasien}

\begin{tabular}{ccc}
\hline Variabel & Kategori & $\%$ \\
\hline LOS & $\begin{array}{c}\text { Sesuai standar } \\
\text { Tidak sesuai } \\
\text { standar }\end{array}$ & 41 \\
& 59 \\
\hline Total & 100 \\
\hline (Sumber:Output Pengolahan Data SPSS21)
\end{tabular}

Tabel 5 menunjukan bahwa LOS pasien dengan kategori sesuai standar sebesar $41 \%$ dan yang tidak sesuai standar sebesar $59 \%$.

\section{Analisa Bivariat}

Analisa bivariat menampilkan pengaruh perawat care giver terhadap LOS pasien (tabel 6) dan pengaruh triage terhadap LOS Pasien (tabel 7).
Tabel 6. Pengaruh Peran Perawat Care Giver Terhadap LOS Pasien

\begin{tabular}{|c|c|c|c|c|c|c|}
\hline \multicolumn{2}{|c|}{ variabel } & \multicolumn{4}{|c|}{ LOS } & \multirow[t]{3}{*}{$p$} \\
\hline & & \multicolumn{2}{|c|}{$\begin{array}{l}\text { Sesuai } \\
\text { standar }\end{array}$} & \multicolumn{2}{|c|}{$\begin{array}{l}\text { Tidak } \\
\text { sesuai } \\
\text { standar }\end{array}$} & \\
\hline & & $\mathrm{n}$ & $\%$ & $\mathrm{n}$ & $\%$ & \\
\hline Peran & Baik & 22 & 53 & 34 & 57 , & 0.694 \\
\hline care & Kurang & 19 & 7 & 25 & 7 & \\
\hline giver & baik & & $\begin{array}{l}46, \\
3\end{array}$ & & $\begin{array}{l}42, \\
3\end{array}$ & \\
\hline Total & & 41 & 41 & 59 & 59 & \\
\hline
\end{tabular}

(Sumber :Output Pengolahan Data SPSS 21)

Berdasarkan tabel 6 diketahui bahwa dari 41 responden LOS yang sesuai standar sebesar $53,7 \%$ mempunyai peran perawat sebagai care giver yang baik dan $46.3 \%$ kurang baik. Dari 59 responden LOS yang tidak sesuai standar sebesar $57,7 \%$ mempunyai peran sebagai care giver yang baik dan $42,3 \%$ yang kurang baik. Penentuan pengaruh peran perawat sebagal care giver dengan lenght of stay pasien di IGD dilakukan dengan uji chi square dan didapatkan $p$ value 0.694 . Nilai $p$ value dibandingkan dengan tingkat signifikansi 0.05 dimana $0.694>0.05$ maka kesimpulannya adalah tidak ada pengaruh peran perawat sebagai care giver terhadap LOS pasien di IGD RSUD dr.T.C.Hillers Maumere.

Tabel 7. Pengaruh Triage terhadap LOS Pasien

\begin{tabular}{|c|c|c|c|c|c|c|}
\hline \multicolumn{2}{|c|}{ Variabel } & \multicolumn{4}{|c|}{ LOS } & \multirow[t]{3}{*}{$P$} \\
\hline & & \multicolumn{2}{|c|}{$\begin{array}{l}\text { Sesuai } \\
\text { standar }\end{array}$} & \multicolumn{2}{|c|}{$\begin{array}{l}\text { Tidak } \\
\text { sesuai } \\
\text { standar }\end{array}$} & \\
\hline & & $\mathrm{n}$ & $\%$ & $\mathrm{n}$ & $\%$ & \\
\hline \multirow[t]{2}{*}{ Triage } & Tepat & 40 & 97, & 59 & 100 & 0.41 \\
\hline & $\begin{array}{l}\text { Tidak } \\
\text { tepat }\end{array}$ & 1 & $\begin{array}{l}5 \\
2,\end{array}$ & 0 & 0 & 0 \\
\hline Total & & 41 & 41 & 59 & 59 & \\
\hline
\end{tabular}

www.jik.ub.ac.id 
Tabel 7 menunjukkan bahwa dari 41 responden LOS yang sesuai standar yang melakukan triage dengan tepat adalah $97,5 \%$ dan yang tidak tepat adalah $2,5 \%$. Dari 59 responden LOS yang tidak sesuai standar yang melakukan triage dengan tepat sebesar $100 \%$ dan yang tidak tepat sebesar $0 \%$. Penentuan pengaruh triage terhadap LOS pasienn di IGD RSUD dr.T.C.Hillers Maumere dilakukan dengan uji fisher dan didapatkan $p$ value sebesar 0.410 Nilai $p$ value dibandingkan dengan tingkat signifikan 0.05 dimana $0.410>0.05$ sehingga dapat disimpulkan bahwa tidak ada pengaruh triage terhadap LOS pasien.

\section{PEMBAHASAN}

\section{Gambaran Pelaksanaan Peran Perawat di Ruang IGD RSUD dr.T.C.Hillers Maumere}

Pelaksanaan penelitian ini di ruang IGD peran perawat di fokuskan pada caregiver. Data yang diperoleh dari observasi peran perawat sebesar $56 \%$ menjalankan perannya dengan baik dan $44 \%$ kurang baik.Secara keseluruhan perawat yang menjalankan perannya sebagai care giver yaitu sebagai pemberi asuhan fisik, psikososial, budaya dan spiritual (Barbara et al,2010\& Potter and Perry, 2005). Peran perawat sebagai care giver di IGD RSUD dr.T.C.Hillers Maumere didasarkan pada alur prosedur pemerikasaan wajib yang ada pada ruang IGD RSUD dr.T.C.Hillers Maumere dimulai dari melakukan triage dimana perawat segera melakukan intervensi dan prosedur organisasi untuk meningkatkan keselamatan pasien dan petugas di Instalasi Gawat darurat (College Emergency Nursing Australia,2007).

Pelaksanaan peran perawat berdasarkan hasil observasi pada perawat IGD RSUD dr.T.C.Hillers Maumere adalah perawat saling komunikasi dan bekerja sama dengan baik, dimana perawat mengidentifikasi masalah klien kemudian mengkomunikasikan hal ini secara verbal atau tertulis pada anggota lain dalam tim kesehatan (Barbara et al,2010 \& Potter and Perry,2005). Komunikasi yang baik secara verbal maupun nonverbal dilakukan oleh perawat terutama pada saat serah terima pasien ke ruang kritis setelah penentuan prioritas kegawatdaruratan, sedangkan secara tertulis dilakukan perawat melalui lembar dokumentasi. Pelaksanaan peran perawat dengan baik juga dipengaruhi oleh tingkat pendidikan akademik perawat dimana pada ruang IGD dari 20 perawat yang bertugas dengan persentase $5 \%$ menempuh jenjang S1 keperawatan, dan 95\% menempuh jenjang D3 keperawatan. Sebuah penelitiann pada tahun 2012 di sebuah rumah sakit di Tanggerang menyimpulkan dengan adanya peran 
perawat yang baik maka akan meningkatkan penanganan pasien pada Instalasi Gawat Darurat (Trisniati et al, 2012). Kemampuan dan keterampilan kerja seseorang dapat diperoleh melalui pendidikan, pelatihan dan masa kerja.Semakin lama waktu yang digunakan seseorang untuk pendidikan dan pelatihan, semakin tinggi kemampuan dan kompetensi melakukan pekerjaan dengan demikian semakin tinggi kinerjanya.

\section{Gambaran Triage di IGD RSUD dr.T.C.Hillers}

\section{Maumere}

Hasil observasi triage perawat terhadap 100 pasien adalah sebesar $99 \%$ adalah tepat dan $1 \%$ tidak tepat. Triage didefinisikan sebagai suatu sistem seleksi dari pemilihan pasien untuk menentukan tingkat kegawatan dan prioritas penanganan pasien (Depkes RI, 2005) Lebih lanjut Oman, K. Koziol-McLain, J., \& Scheetz, (2008) mendefinisikan sebagai suatu konsep pengkajian yang cepat dan terfokus dengan suatu cara yang memungkinkan pemanfaatan sumber daya manusia, peralatan serta fasilitas yang paling efisien dengan tujuan untuk memilih atau menggolongkan semua pasien yang memerlukan pertolongan dan memprioritaskan penanganannya. Proses penilaian atau memprioritaskan pasien untuk memperoleh perawatan medis pada saat kedatangan di IGD didasarkan menurut tipe, tingkat kegawatan, jumlah pasien, ketersediaan sumber daya manusia dan sarana peralatan pendukung.

Pelaksanaan Triage pada ruang IGD RSUD dr.T.C.Hillers Maumere yang dilakukan pada pasien sesuai dengan standar operasional prosedur pelayanan triage. Pada hasil observasi ditemukan bahwa perawat yang bertugas di IGD RSUD dr.T.C.Hillers maumere dapat melaksanakan triage dengan baik. Hal ini di dukung oleh masa kerja dari perawat IGD yang mana perawat yang bekerja dengan masa kerja $>5$ tahun sebesar $60 \%$ dan yang bekerja $<5$ tahun sebesar $40 \%$. Hal ini sejalan dengan beberapa penelitian yakni diantaranya penelitian yang dilakukan oleh Cone (2006). Penelitian ini menunjukkan bahwa faktor yang mempengaruhi pelaksanaan triage desicion making adalah pengkajian, komunikasi, pengalaman bekerja di IGD, instiusi, kemampuan berpikir kritis, pelatihan dan monitoring. Penelitian ini menunjukkan bahwa faktor yang mempengaruhi triage desicion making adalah : pertama faktor kondisi klinis pasien yang meliputi riwayat penyakit sebelumnya, potensial pengobatan, mekanisme cedera. Kedua faktor operasional di unit gawat darurat meliputi tingkat aktivitas di UGD, keterampilan dokter, keterampilan perawat. Ketiga adalah faktor-faktor lain meliputi jenis atau tipe rumah sakit serta pengalaman perawat. Penelitian yang 
dilakukan oleh Fathoni (2013) menunjukkan bahwa terdapat korelasi positif antara keterampilan triage dengan pengetahuan, pelatihan dan pengalaman kerja.

\section{Gambaran Lenght Of Stay Pasien di IGD} RSUD dr.T.C.Hillers Maumere

Hasil observasi terhadap 100 pasien ditemukan bahwa lenght of stay pada pasien di IGD yang sesuai standar sebesar $41 \%$ dann yang tidak sesuai standar 59\%. Standar LOS yang digunakan dalam penelitian ini adalah 6 jam.Secara internasional rekomendasi untuk LOS di ruang gawat darurat yaitu $\leq 8$ jam umumnya dianggap diterima (Rose et al, 2012). Namun di berbagai negara menerapakan 4 jam untuk LOS di ruang gawat darurat seperti di Inggris, Australia, Iran, Kanada dan Amerika. LOS yang ideal di Iran telah dilaporkan empat jam (Jabbari et al, 2011) Namun, hanya 39\% dari pasien Iran memiliki LOS dari lebih pendek dari empat jam (Jabbari et al, 2011) sedangkan di Kanada, Amerika, dan Inggris masing-masing 76\%, 72\%, dan 96-98\% dari pasien telah memiliki LOS dari lebih pendek dari empat jam (Lee \& Yom, 2007) (Coleman P \& Nicholl J, 2010). Standar LOS di IGD RSUD dr.T.C.Hillers Maumere adalah 6 jam.

Berbagai penelitian yang dilakukan untuk melihat Length of Stay di ruang gawat darurat. Penelitian yang dilakuakan oleh Richardson
(2006) dan Bernstein et al (2009).Hasil penelitian mereka menunjukkan bahwa peningkatan lama tinggal di ruang gawat darurat berdampak pada peningkatan mortalitas dan morbiditas pasien. Konsekuensi lain yang dihasilkan dari tinggal berkepanjangan di ruang gawat darurat termasuk ketidakpuasan pasien dan kematian meningkat akibat kecelakaan (Parker BT \& Marco C, 2014). Penurunan dalam memberikan pelayanan kepada pasien yang membutuhkan perawatan mendesak, peningkatan biaya perawatan, staf medis kelelahan dan frustrasi dan bahkan penurunan kemampuan dokter yang diikuti dengan waktu pengobatan meningkat.Mempengaruhi kualitas layanan yang diberikan, keselamatan pasien dan hasil pengobatan. Masalah tersebut dapat meningkatkan jumlah pasien yang meninggalkan ruang gawat darurat dan angka kematian pun meningkat (Storm, Vermeulen, H., van Lammeren, N., Luitse, J. S., \& Goslings, J. C. (2014).)

\section{Pengaruh peran perawat sebagai care giver terhadap lenght of stay pasien di IGD RSUD dr.T.C.Hillers Maumere}

Uji Chi square dilakukan untuk mengetahui pengaruh antara peran perawat sebagai care giver terhadap lenght of stay pasien dan didapatkan hasil $p$ value sebesar $0.694>0.05$ sehingga dapat disimpulkan 
bahwa tidak ada pengaruh peran perawat sebabagi care giver dengan lenght of stay pasien. Berbeda dengan penelitian yang dilakukan oleh Yoon et al (2003) yang menyatakan bahwa peran perawat sebagai care giver berpengaruh pada LOS pasien di IGD dimana mencakup strategi pemeriksaan dan penanganan yang dipilih dalam penanganan berbagai kasus di ruang IGD.

Peran perawat di ukur melalui kemampuan dan keterampilan kerjanya. Dimana dapat diperoleh melalui pendidikan, pelatihan dan masa kerja. Semakin lama waktu yang digunakan seseorang untuk pendidikan dan pelatihan, semakin tinggi kemampuan dan kompetensi melakukan pekerjaan dengan demikian semakin tinggi kinerjanya. Perawat di IGD RSUD dr. T.C.Hillers Maumere selalu bekerja dengan tim interdisiplin, pada saat melakukan tindakan perawat berkolaborasi dengan tenaga kesehatan lainnya. Perawat juga selalu membantu mahasiswa keperawatan, hal ini dapat dilihat bahwa IGD RSUD dr. T.C.Hillers Maumere menjadi lahan praktik bagi mahasiswa keperawatan dari instansi pendidikan kesehatan yang ada di Maumere. Di IGD RSUD dr.T.C.Hillers Maumere sebagian besar perawat memiliki pengalaman kerja $>5$ tahun, sehingga dapat dikatakan bahwa perawat di IGD RSUD dr.T.C.Hillers Maumere mayoritas dalam tahap senior.

Menurut pendapat Amriyati (2012) bahwa pengalaman kerja berpengaruh terhadap kinerja perawat.Menurut Simanjuntak (2005) kinerja seseorang dapat dipengaruhi oleh tiga faktor, yaitu kompetensi individu, dukungan organisasi dan dukungan manajemen.Kompetensi individu adalah kemampuan dan keterampilan melakukan kerja.Kemampuan dan keterampilan kerja seseorang dapat diperoleh melalui pendidikan, pelatihan dan masa kerja. Semakin lama waktu yang digunakan seseorang untuk pendidikan dan pelatihan, semakin tinggi kemampuan dan kompetensi melakukan pekerjaan dengan demikian semakin tinggi kinerjanya

Pada penelitian ini, peran perawat sebagai care giver tidak memberikan pengaruh yang bermakna pada LOS pasien di IGD. Pelaksanaan peran perawat sebagai care givermulai dari pengkajian, menetapkan diagnosa, menetapkan intervensi, melakukan implementasi dan melakukan evaluasi dengan melibatkan perawat lain yang diobservasi tidak berpengaruh secara signifikan dalam penurunan LOS hal ini dikarenakan meskipun perawat sudah menjalankan perannya dengan baik akan tetapi LOS pasien di IGD RSUD dr.T.C.Hllers Maumere banyak dipengarihi oleh faktor-faktor diantaranya seperti 
kelengkapan administrasi dimana pasien tidak dapat dipulangkan atau dipindahkan keruang perawatan jika administrasi pasien belum lengkap. Hal ini bertentangan dengan hasil penelitian yang dilaksanakan di rumah Sakit Royal Victoria Inggris menunjukan hasil bahwa penggunaan tim triage secara signifikan menurunkan waktu pengkajian, waktu tunggu, dan pemindahan pasien selama waktu intervensi pada pasien (Subash F et all, 2003)

LOS pada ruang IGD dipengaruhi juga oleh tingkat kegawatan pasien dimana pada kasus-kasus pasien prioritas 3 lebih banyak dan melebihi standar hal ini juga mempengaruhi ketersediaan tenaga kesehatan di IGD. Sejalan dengan penelitian pada sebuah Rumah Sakit di Jakarta yang meneliti faktor-faktor yang mempengaruhi length of stay pada Rumah Sakit tersebut menunjukan hasil bahwa pasien lansia, pasien dengan kasus emergency berat, pasien rujukan, training ECG untuk dokter dan training advance cardiac life support (ACLS) untuk perawat berhubungan dengan LOS pada unit gawat darurat (Trisniati, E., 2012).

Penelitian lain yang dilaksanakan pada rumah sakit di Melbuern Australia pada tahun 2003 menunjukkan hasil yang serupa yaitu menyimpulkan bahwa LOS pada Instalasi Gawat Darurat berhubungan dengan jenis diagnosa pasien, status usia, jenis kelamin dan waktu kedatangan pasien pada Instalasi Gawat Darurat dan stategi yang di gunakan untuk menurunkan LOS (Termasuk Perbaikan Akses) secara signifikan menurunkan biaya perawatan dan morbiditas pasien (Liew et all, 2003). Secara konseptual LOS dipengaruhi oleh banyak faktor, salah satunya adalah penenganan penderita sejak awal secara tepat dan baik (Lynelle, 1995). LOS memberikan gambaran tingakt efisiensi, juga dapat memberikan gambaran mutu pelayanan yang apabila di terapkan pada diagnosis tertentu dapat dijadikan hal yang memerlukan pengamatan lebih lanjut.

\section{Pengaruh Triage terhadap lenght of stay di IGD RSUD dr.T.C.Hillers Maumere}

Uji Fisher dilakukan untuk mengetahui pengaruh triage terhadap lenght of stay pasien dan didapatkan hasil $p$ valuesebesar $0.410>0.05$ sehingga dapat disimpulkan bahwa tidak ada pengaruh triage dengan LOS pasien.

Hasil observasi menunjukan bahwa triage yang dilakukan oleh perawat IGD RSUD dr.T.C.Hillers Maumere hampir semuanya dilakukan dengan tepat. Sesuai standar DepKes RI bagi perawat yang bekerja di IGD dan yang melakukan adalah perawat yang telah bersertifikat pelatihan PPGD (Penanggulangan Pasien Gawat Darurat) atau 
BTCLS (Basic Trauma Cardiac Life Support). Hampir seluruh perawat yang bekerja diruang IGD RSUD d.r.T.C.Hillers Maumere mempunyai sertifikat pelatihan PPGD, ini merupakan standar yang harus dimiliki oleh seorang perawat IGD. Pengalaman kerja juga mempengaruhi seorang perawat dalam melalukan triage. Data umum karakteristik perawat yang dilihat dari masa kerja menunjukan bahwa dalam kategori masa kerja perawat di ruang IGD dikategorikan pada $>5$ tahun dengan persentase jumlah perawat sebesar $60 \%$ dan 3-5 tahun sebesar $40 \%$. Perawat yang bekerja di IGD RSUD dr.T.C.Hillers Maumere semuanya telah mengikuti pelatihan kegawatdaruratan yaitu 90\% perawat pernah mengikuti PPGD, 10\% pernah mengikuti PPGD dan BCLS. Berdasarkan tingkat pendidikan, 95\% perawat masih berpendidikan D3 Keperawatan dan 5\% perawat berpendidikan S1 Keperawatan.

Seperti yang dijelaskan oleh Oman (2008) bahwa pengetahuan, sikap dan ketrampilan petugas kesehatan IGD sangat dibutuhkan dalam pengambilan keputusan klinis agar tidak terjadi kesalahan dalam melakukan pemilahan saat triage sehingga dalam penanganan pasien bisa lebih optimal dan terarah. Pelaksanaan triage juga dipengaruhi oleh usia seseorang. Hasil penelitian menunjukan bahwa presentase usia perawat pada ruang IGD adalah $45 \%$ berusia $>35$ tahun dan $55 \%$ berusia $\leq 35$ tahun. Menurut Notoadmojo (2005) usia mempengaruhi terhadap daya tangkap dan pola pikir seseorang, semakin bertambah usia, akan semakin berkembang pula daya tangkap dan pola pikirnya sehingga pengetahuan yang diperoleh semakin baik. Kematangan individu dapat dilihat langsung secara objektif denga periode umur, sehingga berbagai proses pengalaman, pengetahuan, ketrampilan, kemandirian terkait sejalannya dengan bertambahnya umur individu. Pada usia dewasa awal petugas kesehaatan yang sudah terlatih dapat melakukan tindakan triage karena usia dewasa adalah waktu pada saat seseorang mencapai puncak dari kemampuan intelektualnya (King, 2010).

Penelitian oleh Fathoni (2013) menunjukkan bahwa terdapat korelasi positif antara keterampilan triage dengan pengetahuan, pelatihan dan pengalaman kerja. Tingkat kematangan dalam berpikir dan berperilaku dipengaruhi oleh pengalaman kehidupan sehari-hari. Hali ini menunjukan bahwa semakin lama masa bekerja akan semakin tinggi tingkat kematangan seseorang dalam berpikir sehingga lebih meningkatakan pengetahuan yang dimiliki. Lama bekerja seorang petugas kesehatan IGD dapat melakukan triage minimal memiliki masa kerja $>2$ tahun (Sunaryo,2004). Semakin lama seseorang bekerja semakin banyak kasus yang 
ditanganinya sehingga semakin meningkat pengalamannya, sebaliknya semakin singkat seseorang bekerja maka semakin sedikit kasus yang ditanganinya (Sastrohadiwiryo,2002)

Menurut Perimal, Ben-Tovin, Hakendorf, \& Thompson (2014) menyatakan bahwa perawat mengklarifikasikan pasien berdasarkan kebutuhan dasar mereka untuk medapatkan pelayanan medis dimana pasien dengan kebutuhan medis tertinggi akan diberikan prioritas pertama. LOS merupakan indikator yang efektif untuk menilai kinerja dari IGD dan kualitas dari triage. LOS yang memanjang berhubungan erat dengan kualitas triage dan kinerja pelayanan keperawatan di IGD (Yoon, 2003; Bukhari et all, 2014; Lewil et al, 2014; Parker, 2014).

\section{KESIMPULAN}

Observasi perawat yang menjalankan peran sebagai care giver dengan baik pada pasien sebesar 44\%, perawat yang menjalankan peran sebagai care giver dengan kurang baik sebesar 56\%. Perhitungan lenght of stay pasien pada ruang IGD yang sesuai standar sebesar $41 \%$ dan yang tidak sesuai standar sebesar 59\%. Observasi pelaksanaan triage

\section{DAFTAR PUSTAKA}

Amriyati, S. (2003). Kinerja Perawat Ditinjau Dari Lingkungan Kerja dan Karakteristik Individu (Studi Pada Instalasi Rawat Inap perawat pada ruang IGD yang tepat sebesar $99 \%$ dan yang tidak tepat sebesar $1 \%$. Tidak terdapat pengaruh peran perawat sebagai care giver terhadap LOS pasien di IGD RSUD dr.T.C.Hillers Maumere $(p=0,694)$. Tidak terdapat pengaruh triage terhadap LOS pasien di IGD RSUD dr.T.C.Hillers Maumere $(p=0.410)$ Bagi perawat disarankan untuk meningkatkan skill terkait penanganan pasien, pemahaman kasus, sehingga dapat mewujudkan pelayanan prima sesuai dengan standar yang ditetapkan oleh Rumah sakit maupun standar nasional. Bagi rumah sakit adanya penetapan prosedur layanan pada ruang IGD yang sesuai standar pelayanan baik secara lokal maupun nasional harus ditetapkan pihak rumah sakit mengacu pada point-point penilaian kinerja klinis tenaga kesehatan yang difokuskan pada mutu pelayanan pasien. Bagi peneliti selanjutnya guna memperbaiki dan menyempurnakan hasil penelitian ini dengan memperbaiki setiap kekurangan yang ada diantaranya menambah jumlah sampel, menambah waktu penelitian, memperbaiki metode observasi dan melakukan penelitian lebih lanjut terhadap faktor-faktor yang berpengaruh terhadap LOS pasien.

Rumah Sakit Umum Banyumas Unit Swadana Daerah)-Nurse Performance Showed By Work. Jurnal Manajemen Pelayanan Kesehatan, 6. 
Australian Government Department of Health and Ageing. (2011). What is mental illness. Canberra: National Mental Health Strategy.

Barbara, K., Erb, G, et al. (2010). Buku Ajar Fundamental Keperawatan (Konsep, Proses dan Praktik) Volume 2. Jakarta :EGC.

Bernstein, S. L., Aronsky, D., Duseja, R., Epstein, S., Handel, D., Hwang, U., et al. (2009). The effect of emergency department crowding on clinically oriented outcomes. Academic Emergency Medicine, 16(1), 1-10

Bukhari et al. (2014). Analysis of Waiting Time In Emergency Department Of Al-noor Specialist Hospital, Makkah, Saudi Arabia. Journal Of Emergency Medicine (2) $67-73$

College Emergency Nursing Australia. (2007).

Emergency Departement Model OfCare. NSW Ministy of Health.

Cone, K.J. And Murray R. (2002). Characteristics, Insight, Desicion Making and Preparation Of ED Triage Nurses. Journal Of Emergency Nursing.28(5).p.401-406

Departemen Kesehatan. (2005). Pedoman Pelayanan Keperawatan Gawat Darurat. Jakarta.

Elliot, D., Aitken, L., Chaboyer, W. (2007). ACCN's Critical Care Nursing. Australia: Elsevier.
Fathoni, M., Sangchan, H., \& Songwathana, P. (2013). Relationships between Triage Knowledge, Training, Working Experiences and Triage Skills among Emergency Nurses in East Java, Indonesia. Nurse Media Journal of Nursing, 3(1), 511-525.

Jabbari, A., Jafarian, M., Khorasani, E., Ghaffari, M., \& Majlesi, M. (2011). Emergency department waiting time at Alzahra Hospital. Director General,8(4), 500-11.

King, A. Laura (2010). Psikologi Umum. Jakarta : Salemba Humanika.

Kocher, K. E., Meurer, W. J., Desmond, J. S., \& Nallamothu, B. K. (2012). Effect of testing and treatment on emergency department length of stay using a national database. Academic Emergency Medicine, 19(5), 525-534.

Lee, M. A., \& Yom, Y. H. (2007). A comparative study of patients' and nurses' perceptions of the quality of nursing services, satisfaction and intent to revisit the hospital: A questionnaire survey. International journal of nursing studies,44(4), 545-555.

Liew, D., Liew, D., \& Kennedy, M. P. (2003). Emergency department length of stay independently predicts excess inpatient length of stay. Medical Journal of Australia, 179(10), 524-527. 
Mortimore, A., \& Cooper, S. (2007). The "4hour target": Emergency nurses' views.

Emergency Medicine Journal, 24(6), 402-404.

Nieils, et al. (2012). Time Series Analysis Of Emergency Department Length OfStay Per 8-Hour Shif. West Journal Emergency Medicine. May 13 (2) : 163- 168

Oman, K. S., Koziol-McLain, J., \& Scheetz, L. J. (2008). Panduan Belajar Keperawatan Emergensi. EGC.

Parker, B. T., \& Marco, C. (2014). Emergency department length of stay: accuracy of patient estimates. Western Journal of Emergency Medicine,15(2).

Potter., PA \& Perry G. (2005). Buku Ajar Fundamental Keperawatan.Konsep, proses dan praktek.EC.Jakarta).

Richardson, D., Kelly, A. M., \& Kerr, D. (2009). Prevalence of access block in Australia 2004-2008. Emergency Medicine Australasia, 21(6), 472-478.

Rose, L., Gray, S., Burns, K., Atzema, C., Kiss, A., Worster, A., ...\& Lee, J. (2012). Emergency department length of stay for patients requiring mechanical ventilation: a prospective observational study. Scand J Trauma Resusc Emerg Med, 20(1), 30.
Sastrohadiwiryo, B. S. (2002). Manajemen tenaga kerja Indonesia.

Storm-Versloot, M. N., Vermeulen, H., van Lammeren, N., Luitse, J. S., \& Goslings, J. C. (2014). Influence of the Manchester triage system on waiting time, treatment time, length of stay and patient satisfaction; a before and after study. Emergency Medicine Journal, 31(1), 13-18.

Simanjuntak (2005). Manajemen dan Evaluasi Kinerja. Lembaga Penerbit Fakultas Ekonomi Universitas Indonesia.

Subash, F., Dunn, F., McNicholl, B., \& Marlow, J. (2004). Team triage improves emergency department efficiency. Emergency Medicine Journal,21(5), 542-544.

Sutawijaya, R. B. (2009). Gawat Darurat, Aulia .Yogyakarta : Publishing.

Sunaryo, S., \& Kes, M. (2004). Psikologi Untuk Keperawatan. Jakarta: Rajawali Pers.

Trisniati, Eni. (2012). Hubungan Pengetahuan Tentang Cidera Kepala dan Peran Perawat Dalam Penanganan Pasien Cidera Kepala Di IGD RS QADR Tanggerang Tahun 2012.

Undang-undang Republik indonesia nomor 36 tahun 2008 tentang kesehatan. 
Yoon, P., Steiner, I., \& Reinhardt, G. (2003).Analysis of factors influencing length of stay in the emergency department. Cjem, 5(03), 155-161. 